\title{
Funes el Memorioso navštěvuje muzeum aneb Vzpomínky na budoucnost ${ }^{1}$
}

\author{
Funes el Memorioso Visits the Museum: Memories of the Future \\ Eva Šlesingerová
}

\begin{abstract}
Using Jorge Borges' fabulous novel and its character Funes el Memorioso, this text describes through Funes' curiousness and strangeness the problem of memorizing processes and their social representation, especially their construction within the lebenswelt. Acts of remembering and forgetting are shown as specific classifying, interpretative hermeneutic inter-subjective activities. The text's main arguments also revolve around the analysis of museums as institutional, material, scientific and futureoriented places of memory. In light of the anthropological reflection of the Western conceptualization of time, the text analyzes the J.G. Mendel Museum of genetics and heredity. Furthermore, the representation of the western modernist time line is examined as a specific continuum, inter-connecting ideas of the past, present and future.
\end{abstract}

KEYWORDS exhibition, genetics, memory, museums, social memory

\author{
Na začátek... \\ Představení Funese a jeho situace
}

Měl ted' neomylnou schopnost vnímání a neselhávající pamět'. My jedním pohledem obsáhneme tři sklenice na stole. Funes obsáhl všechny výhonky, hrozny a bobule na dřevěné mř́iži porostlé vinnou révou. Pamatoval si podobu všech mraků na jižní obloze za svítání třicátého dubna roku osmnáct set osmdesát dva a mohl ji ve vzpomínkách porovnávat s žilkováním na kožené vazbě knihy, kterou viděl jen jednou, i s pruhy pěny, kterou na hladině řeky Rio Negro zanechalo veslo v prredvečer bitvy u Quebracha. Přitom nešlo o jednoduché vzpomínky. Každý jeho zrakový vjem byl spojen se svalovými a tepelnými pocity atd...

(Jorge Borges, Zrcadlo a maska)

Funes el Memorioso - tak celým jménem nazval argentinský spisovatel Jorge Borges hlavní postavu své povídky „Funes el Memorioso - muž se zázračnou pamětí“. Funes je člověk, který vyniká mimořádnou schopností pamatovat si naprosto vše, každý okamžik, myšlenku, pocit, vjem. Jako každá mimořádnost, je i ta jeho ambivalentní. Má přinejmenším dvě strany - fascinující a hrozivou. Mimořádný Funes je, zdá se, vlastně uvězněn ve světě nikdy

Sociální studia. Fakulta sociálních studií Masarykovy univerzity, 1/2010. S. 43-57. ISSN 1214-813X.

1 Text vznikl v roce 2009 jako součást přípravného přemýšlení a před-výzkumných prací na terénním etnografickém výzkumu „Místa paměti“ vznikajícím v rámci Institutu pro výzkum reprodukce a integrace společnosti na FSS MU v Brně. 
nekončících vzpomínek a je odsouzen k promítání si nikdy nekončícího filmu svých zážitků a myšlenek. Tento muž upoutaný ke svým vzpomínkám je tedy poněkud obdivuhodným i děsivým obrazem něčeho nemožného - úplného obnovení minulosti. Uchovávat bez výběru ovšem není práce paměti. Např́ílad pro Tzvetana Todorova není pamět’ opakem zapomnění. Dvěma komplementárními póly jsou vymazáni (zapomnění) a uchování, přičemž pamět' je vždy a nutně interakcí obou (viz Todorov 1998: 93-94).

To, co Todorova a koneckonců nás všechny, kdo si kdy přečetli fabulaci Jorge Borgese, mírně znejistí, je představa naprosté nestrukturovanosti vjemů, zážitků, pocitů, a tudíž vlastně chaotičnost identity, prázdnota $\mathrm{v}$ mnohosti, nevýznamnost $\mathrm{v}$ prostoru bez výběru významu. A tak pokud se $\mathrm{v}$ tzv. reálném světě mimo literární příběhy ocitne člověk ve Funesově situaci, je odsouzen $\mathrm{k}$ zájmu lékařů, ostatních expertů, médií, svého okolí. Měl by si pod tlakem okolí přiznat, že má problém. Sice zajímavý, ale problém. To, co se v románové fikci zdá být součástí fantazie, a ne tedy tím, co jsme si uvykli chápat jako „neskutečné“, ,jen představované“, nemusí být ale až tak nereálné, jak se na první pohled zdá. Zpráva o prožívání krajních hranic lidské paměti, Funese i jeho protějšku z žitého světa, rríká, že v Kalifornii žije jistá jednačtyrícetiletá úřednice, jejíž př́pad lékařská literatura popisuje iniciálami A. J. Tato žena si pamatuje každý okamžik svého života od svých jedenácti let. ${ }^{2}$ Funes z reálného světa, úřednice A.J., ř́ká: „Moje pamět' běží jako film, bez prestání a bez kontroly.“ Pamatuje si, že v neděli 3. srpna 1986 ve 12:34 jí zatelefonoval jistý mladý muž, do kterého byla bláznivě zamilovaná... Pamatuje si světové události i cesty za nákupem, počasí i své pocity. V její paměti je uloženo prakticky všechno... uchování minulosti se stalo ústředním motivem jejího života. „Když si suším vlasy fénem, vzpomenu si, co je za den. A abych se trochu zabavila, v duchu si projdu týž den za posledních dvacet let - jako bych listovala v kartotéce“ (viz Foer 2007: 77).

Uvnitř biologického a biomedicínského diskurzu ${ }^{3}$ se konstatuje, že tuto kartotéku vjemů tř́dí a klasifikuje naše nervová soustava. Tedy součinnost mezi smyslovými orgány a mozkem. Smyslem tohoto propletence je pak za pomoci vybavování toho, co jsme zažili v minulosti, zpracovávání toho, co se děje v př́ítomnosti, a předvídání a př́ípravy na to, co se bude dít v budoucnosti, jak co nejlépe reagovat. $V$ reprezentaci tohoto vysvětlení aktu lidské paměti v každodenním vědění postkartesiánského západního světa je mozek strojem na předpovídání a má-li fungovat, potřebuje nalézt rád v chaosu dostupných vzpomínek, protože většinu věcí, které projdou mozkem, je záhodno zapomenout ve chvíli, kdy o nich přestaneme uvažovat.

Pokud při přemýšlení o Funesově problému vezmeme v úvahu i jiné než biomedicínské paradigma vysvětlení paměti jako činnosti mozku a systému přenosů neuronových vzruchů, můžeme porozumět této situaci taky tak, že pamět’ člověka a ostatních sociálně žijících

2 Na druhém konci pomyslného kontinua paměti stojí oproti A. J. pětaosmdesátiletý laboratorní technik E. P., který si pamatuje pouze své současné myšlenky a vjemy nebo zážitky ze vzdálené minulosti, tedy hlubokou minulost nebo tu z posledních tří minut. Současný a budoucí svět tedy žije prostřednictvím minulých tří minut. Zajímavé na situaci E. P. je to, že tzv. habituální pamět' mu zůstala v podstatě neporušena. Tedy ta část paměti, která je neuvědomovaná, vepsaná do těla řadou zkušeností. Tzn. dokáže se orientovat v prostoru, pamatuje si cestu domů, i když neuvědomovaně. Tedy tak, jak moderní západní věda uvažuje o kategorii „živého“, o „člověku“. 
tvorů je specifická tím, že je jak individuální, tak i intersubjektivní a hermeneuticky pracující. Individuální pamět’ jakožto vrstvení informací, vjemů, lidí, zážitků, pocitů je jak autobiografickou, kognitivní, habituální, ne-textuální aktivitou, tak i aktivitou sociální. Na jedné straně přináší a zpř́tomňuje minulost skrze myšlení, kulturně danou reprezentaci času a na tento čas orientované jednání. ${ }^{4}$ Právě vědomé i nevědomé připomínání si minulosti a její chápání jako minulého, je oním aktem, který nazýváme „pamětí“ v obecném smyslu. Člověk pak skrze tyto aktivity paměti tvaruje smysluplné narativní sekvence. Pamět’ je tak více méně vědomou aktivitou uspořádávání či narativní organizace. Vzpomínání, zapomínání, práce paměti neexistuje ale na straně druhé mimo sociální tlaky a vlivy. Což nás opět přivádí $\mathrm{k}$ další a $\mathrm{z}$ hlediska sociálních věd důležité dimenzi studia paměti - k její sociální, kolektivní stránce. Vztah mezi individuální a sociální pamětí je zde podobný jako mezi langue a parole (viz Misztal 2003:9-12). Nebo jako vztah mezi aktérem a strukturou, který vzniká skrze agency. Jde tedy o v každém okamžiku zpř́tomňované sociálně strukturované a individuálně prožívané vzpomínání/zapomínání.

Aspektem paměti, tedy tím, co z Funese udělalo mimořádného člověka - a prece tragéda -, byla vlastně jeho ztráta sebe sama $\mathrm{v}$ toku času, neschopnost nejen zapomínání, třídění, ale také neexistence ani náznaku schopnosti vztáhnout se $\mathrm{k}$ abstrakci času ani jako mytického, ani jako směřujícího od kořenů dávnověku $\mathrm{k}$ budoucnu. Funes si není vědom své osobní ani sociální identity v čase. Je možná stejně tak jako exulanti člověkem v čase sice uvězněným, ale zároveň mimo čas a prostor, mimo vlastní „dějiny““ (smysl v čase), i když si této ztráty narozdíl od emigrantů skrze svoji neschopnost nadhledu a reflexe není vědom. Tudíž není vystaven emocím, které reagují na tuto ztrátu kontinuity. ${ }^{5}$

\section{Hodiny, kalendáře a pýcha Evropanů}

Dalším důležitým aspektem analýzy Funesovy situace je zmínka o vztahu mezi dvěma elementy dichotomie, v níž vedle sebe/proti sobě stojí primitivní pamět' versus civilizovaná historie. Na jedné straně ahistoričnost tzv. tradičních, neliterárních společností, a na druhé straně uvědomovaná a nárokovaná lineární historicita společností moderních, západních. Specifické je přesvědčení Západu o tom, že čas je něco, co můžeme vlastnit, čeho může mít

4 Např. v případě habituální paměti těla zpřítomňuje do velké míry nereflektovanou, podvědomou pamět' těla.

5 „Aspekty identity, ktoré v procese migrácie prechádzajú zásadnými zmenami, zahrňujú čas a priestor. Spôsob, akým exulanti zažívajú čas a priestor, je zásadným v konštrukcii identít ,na-pomedzí (in-between). Homi Bhabha píše o ,vylučovacej, okrajovej časovosti parciálnych, minoritných kultúr' (viz Bhabha 1996: 56). Exulanti sú vždy mimo čas a miesto, pretože je im odmietaný neobmedzený prístup $\mathrm{k}$ ich pôvodným a tiež k osvojeným domovinám. Exulanti, a migranti vo všeobecnosti, nie sú však zbavení iba svojej domoviny, sú tiež zbavení svojej minulosti. ... Všetci migranti zanechávajú za sebou svoju minulost', aj ked' sa ju niektorí snažia zabalit' do uzlíčkov a krabíc. Cestou sa ale z prechovávaných spomiekových predmetov a starých fotografií niečo vytratí, až ich nakoniec nepoznávajú ani ich vlastní majitelia, pretože osudom migrantov je, aby boli obraní o dějiny, aby stáli nahí uprostred opovržlivých pohl'adov neznámych, na ktorých vidia drahé šaty, brokát kontinuity a obočie spolupatričnosti““ (Metyková, 2004: 71-77). 
člověk hodně nebo málo; je to něco, co lze ušetřit; co je možné vyjádřit penězi a co lze měřit nezávisle na konkrétních událostech. Pojmy jako ,jedna hodina“ nebo „jeden týden“ mají smysl dokonce i tehdy, když neřekneme, jaké události jsou jejich obsahem. V našem typu společnosti je čas znázorněn jako čára s šipkou na konci, kde jeden pohyblivý bod označovaný jako „prítomnost“ odděluje minulost od budoucnosti (viz Eriksen 2008: 293-294). Čas je sice změřitelnou fyzikální veličinou našeho světa, není ovšem jeho veličinou ontologickou. Představy a pojetí času vytváŕí jejich sociální a kulturní kontext. Je také důležitou vlastností specifických diskurzivních podmínek, ve kterých se konstituují sociální identity, různé politiky vzpomínání i zapomínání. Čas, jakožto specifický typ abstrakce, je tedy kulturním vynálezem, nic víc a nic méně. Hodiny a kalendáre $v$ jistém smyslu čas neměří, ale vytvářejí. ${ }^{6}$

$\mathrm{S}$ tímto souvisí další vrstva porozumění situaci Funese, kterou je vztah paměti (individuální a sociální, kolektivní) ke strukturovanému, experty a zvláštní vědeckou disciplínou posvěcenému vědění $\mathrm{v}$ podobě historie. $\mathrm{V}$ podobě historie jakožto vědy, která podporuje vizi světa, v níž představa o abstraktní entitě, jako je čas, s sebou nese smysl, určitou filozofii př́běhů měst, komunit, etnik, národů apod. Jde tedy o vztah mezi ahistoricky vnímanými tradičními společnostmi a Západem s moderním časem a šipkou směřující $\mathrm{k}$ budoucímu. Jak píše Lévi-Strauss ve svém textu Myšlení primitivnich národì, historie opravdu úplná by nás postavila tváří v tvář chaosu. Historie ale není absolutní, vždy je historií „pro někoho“. Předpokládaná „,koherence“ dějin, kterou západní myšlení považuje za předmět svého studia, je koherencí mýtu. Je výsledkem užití narativních strategií, pomocí nichž jsou základní jednotky př́běhu (nebo skupiny událostí) uspořádány tak, aby dodaly nějaké čistě lidské struktuře nebo lidskému procesu podobu kosmické (nebo prírodní) nutnosti, adekvátnosti nebo nevyhnutelnosti. „Př́běhy o založení měst nebo států, o původu třídních rozdílů a výsad, o fundamentálních sociálních transformacích, jakými jsou revoluce a reforma... stejně tak jako historie, historický čas nejsou jednou provždy dané, přrirozené a nezměnitelné. Do toku času importovaná změna, pokud je dostatečně legitimizovaná, může vypadat jako přirozená, myticky samozřejmá" (Lévi-Strauss 1996). Historie jakožto historie národního vývoje ustavila na Západě nejsilnějš́i kolektivní tradici paměti, naše typické prostř̌edí paměti. A pamět’ zde byla uchvácena historií. Jistota vědění o světě byla těmito národními historiografiemi popisována v podobě př́běhů směřujících $\mathrm{k}$ pokroku civilizace používající mytologii původu, kořenů, časové linie táhnoucí se $\mathrm{z}$ minulosti $\mathrm{k}$ budoucímu lepšímu světu. V moderní době tak

6 „Společnosti, které nemají hodiny, čas nepostrádají. [...] V tomto typu společnosti - a z historického hlediska je to naprostá většina společností - existuje pouze čas zakotvený v činech a v procesech. Neexistuje jako něco abstraktního a autonomního mimo určité události. Rituály se neodehrávají ,v pět hodin', ale tehdy, kdy je všechno připraveno. [...] Ve společnosti bez hodin není čas vzácným zdrojem, protože existuje pouze v podobě událostí. Člověk nemůže čas ,ztrácet‘ ani ,zabíjet ‘[...] ,Francouzi si myslí, že jsou větší než Bůh, “ ríkali Kabylové, ,protože jsou přesvědčeni, že mohou ovládat budoucnost.‘ [...] Mnohé národy nečasují slovesa v budoucím čase [...] přesvědčené, že čas se rodí teprve v souvislosti s událostmi, a protože budoucí události ještě nenastaly, nemůže budoucnost vytvořit čas. [...] Stejně jako písmo byl i čas nejprve rozvíjen pro rituální účely. Prvními evropskými uživateli hodin byli mniši, kteří potřebovali koordinovat své modlitby“ (Eriksen 2008: 293-294). 
vzniká kult kontinuitȳ, v němž skrze minulost uctívá západní společnost svoji kosmologii většího pokroku. Skrze výběr z minulosti nachází svůj smysl a jistotu v sobě (viz Nora 1998).

Zpět k Funesovi a k naší stati o paměti. Postava či metafora Funese nás bude provázet celým textem, prostřednictvím kterého se snažíme porozumět jeho obtížné situaci. Úvaha začala tím, že poukázala na důležitost dialektického vztahu mezi individuální a sociální pamětí, na důležitost toho, že součástí identity-tvorné schopnosti paměti je jak vzpomínání, tak i zapomínání. Absence této schopnosti činí z Funese značně obskurní postavu či v realitě podivu-hodného, možná nemocného člověka. Poté se text obrátí ke konkrétnímu přemýšlení o socialitě pamatování, o místech paměti, tak jak je definuje francouzský historik Pierre Nora, proto, abychom na konkrétním př́kladu Muzea J. G. Mendela, muzea dědičnosti a genetiky, ukázali, jak může institucionalizovaná a materializovaná pamět' přispět k oživování moderní ideje Západu o kontinuitní linii času plynoucího mezi minulostí, př́itomností a budoucností. Díky tomuto, obrazně řečeno, $\mathrm{v}$ předposlední kapitole vzpomínáme na budoucnost. Totiž na budoucnost, jejiž stopy jsou skrze geny a ideu dědičnosti muzeem vepsány již do minulosti, kterou jednotlivé expozice/výstavy reprezentují. Text tedy poukáže opět na potíže Funese, jenž by při své návštěvě nebyl sto rozpoznat onu linii, osu, podle které je vyprávěn př́iběh konkrétního muzea genetiky. Na závěr se vrátíme opět do literární fikce, fantazie a text se rozloučí vzpomínkou na věštění minulosti obyvateli Maconda jako metaforického opaku Funese el Memoriosa - hlavní postavy našeho príiběhu.

\section{Místa paměti - muzea}

Časoprostor a zrcadlo

Zvědavost ohledně míst v nichž se krystalizuje a do nichž se utíká jako pamět' v tomto konkrétním okamžiku naší historie. Okamžik klíčový, v němž se vědomí rozchodu s minulostí mísí s pocitem rozervané paměti; kde však tato trhlina probouzí ještě dost paměti na to, aby mohl být nastolen problém jejího vtělení. Pocit kontinuity se stává usazeninou, shromážděnou v určitých místech. (Nora 1998: 7)

Hra paměti a historie konstituuje podle Pierra Nory (viz Nora 1998) tzv. mista paméti. Nora píše o místech paměti, která spojují materiální, symbolické a funkční prvky. Symboličností se místa paměti plní skrze obraznost, propůjčující svoji auru například prostřednictvím mytologie př́iběhů a kosmologií o stvoření světa/národa/města, materiální místa jsou např́iklad muzea či archivy, složky a skladiště archivu; funkční složkou míst paměti mohou být školní učebnice, sdružení bývalých spolubojovníkủ či závět'. Všechny tři tyto charakteristiky se ale propojují na každém místě paměti, prolínají se různou měrou a intenzitou. Muzeum je místem paměti, pouze pokud je mu propůjčena symbolická hodnota, památník je místem paměti, pouze pokud je živý rituál a existují materie, které jej ztělesňují, či významy, které jej naplňují symbolickou hodnotou. Místa paměti se rodí a žijí z pocitu, že neexistuje

7 Diskontinuitní situace: exulanti, transformace, historické ikonografické boje a fantastové, vytváření nových pamětí, reinterpretace minulosti jako zdroje současné identity. 
žádná spontánní pamět', že je třeba vytvářet archivy, je třeba slavit výročí, organizovat oslavy, pronášet smuteční projevy, protože tyto úkony nejsou přirozené. Vznikají archivy paměti, v nichž pamět' je povinností, profesionální službou. Pamět' ale také funguje ve vztahu ke vzdálenosti času - a zde nejde již o retrospektivní kontinuitu, nýbrž o osvětlení diskontinuity (viz Nora 1998: 14-20). A jedním se zásadních míst paměti se tak stává muzeum, archiv...

Muzeum je svého druhu specifický časoprostor - heterotopie, tak jak o tom píše Michel Foucault, když uvažuje o „místech vněǰ̌ku“ se zvláštními vlastnostmi. Takovými, jež zpochybňují, neutralizují, nebo převracejí soubor vztahů, které označují, zrcadlí nebo reflektují. Jsou podle něj dva základní typy těchto prostorů, které mají vztah ke všem ostatním, a přesto je popírají. Nazývá tato místa utopie a heterotopie a spojuje je ve zkušenosti zrcadla, které je zároveň utopické - tedy neskutečné, stínové zobrazení místa, kde nejsme - a zároveň heterotopické, tedy skutečné, a potud působící na situaci před zrcadlem. ${ }^{8}$ Heterotopie jsou podle Foucaulta nejčastěji spojeny s časovými řezy, tzn. otevřeny heterochronii. „Heterotopie začíná plně fungovat ve chvíli, kdy se člověk dostane do určité absolutní roztržky s tradičním časem. Z obecného hlediska jsou ve společnosti, jako je naše, heterotopie a heterochronie strukturovány a distribuovány relativně komplexně. Nejprve jsou tu heterotopie věčně se akumulujícího času, jako jsou např́klad muzea a knihovny“ (Foucault 2003: 81-82).

Muzea a knihovny jsou heterotopie, ve kterých se čas nikdy nepřestává kupit a dosahovat svého vrcholu, zatímco ještě na konci 17 . století byla muzea a knihovny výrazem volby jednotlivce. Naproti tomu myšlenka shromažd’ování všeho, založení jakéhosi všeobecného archivu, vưle uzavřít do jediného místa všechen čas, všechny doby, všechny formy, všechny proměny vkusu, myšlenka vybudování místa všech časů, které samo je mimo veškerý čas a jeho ničivé účinky, plán uspořádat tímto způsobem jistou neustávající a nekonečnou akumulaci času v jednom nepohyblivém místě, celá tato myšlenka patří k naší modernitě. Muzeum a knihovna jsou heterotopie vlastní západní kultuře 19. století. (Foucault 2003: 81-82)

Jednou částí analýzy a interpretace těchto míst, těchto umístění paměti, je to, co Lidchi nazývá poetikou vystavování, tzn. sledování toho, jak vizuální jazyk fotografií sémanticky vyjadřuje význam, různorodosti způsobů, jak muzeum a konkrétní výstava vytváŕí, reprezentuje kulturu. Druhou stranou je analýza politiky vystavování, toho, jak diskurz, moc, instituce galerie, muzea v konkrétním čase a prostoru vybírá, komentuje či spravuje vystavovaný

8 „Nejprve jsou tu utopie. Utopie jsou umístění bez skutečného místa. Jsou to umístění, která jsou vůči skutečnému prostoru společnosti v obecném vztahu přímé nebo nepřímé analogie. Utopie, to je dokonalá společnost sama, nebo společnost převrácená; utopie jsou však v každém případě místa zásadně neskutečná. Pravděpodobně v každé kultuře, v každé civilizaci, jsou skutečná místa, místa, která existují, která se formují v samotném základu společnosti - která jou něco jako proti-umístění, druh účinně zavedených utopií, v nichž skutečná umístění, všechna ostatní skutečná místa, která můžeme v kultuře najít, jsou současně reprezentována, popírána a převracena. [...] Protože tato místa jsou zcela odlišná od všech ostatních umístění, která reflektují a o nichž mluví, budu je nazývat, jako určitý protiklad vůči utopiím, heterotopie. Věřím, že někde mezi těmito utopiemi a těmito naprosto jinými místy, heterotopiemi, může být určitý druh smíšené, provázané zkušenosti, jíž je zrcadlo“ (viz Foucault 2003: 75-76). 
materiál (viz Lidchi 1997). Význam okolního, at' už minulého, či současného světa i jeho vizuálních reprezentací je vždy pře/vytvářen, produkován, ne/nalezen. Na této činnosti narativního strukturování si můžeme uvědomit fungování procesů, které Freud ve svém Výkladu snů přesvědčivě ukazuje jako součásti jakékoli poetické aktivity, ${ }^{9}$ at' již bdícího, nebo spícího vědomí (viz White 1996).

Archivářova nebo muzejníkova - fakticky pečlivá, nicméně imaginaci a diskurzům politiky podléhající - rekonstrukce minulosti by nevznikla bez silného pocitu nostalgie, bez touhy najít či vytvořit kořeny, vystopovat zestárlý a unavený svět v ještě zárodečném stavu. „Stroj času neexistuje. Kdo tvrdí, že ho snad i ovládá, lže. A pritom po věcech a stavech, které nelze uchopit, přivlastnit si, prožít, tolik toužíme“ (Komárek 2008: 5). Kurátoři v muzeu již tedy nejsou považováni za nenapadnutelné/nedobytné držitele vědění o svých sbírkách, ne-politické ${ }^{10}$ aktéry, muzea již nejsou uctívána jako místa poskytující vědění a osvícení, samozřejmé místo pro historicky a kulturně důležité objekty. Analýza archivu jako analýza heterotopie s nárokem na zrcadlení skutečnosti je nám nablízku, ale zároveň mimo naši skutečnost, je hranicí času, která obklopuje prítomnost. Archiv je místem jakožto odchylka našich vlastních diskurzivních praktik. ${ }^{11}$

\section{Kabinet kuriozit a místo bohyň}

Muzeum, archiv a jejich sbírky postupně vznikly z encyklopedické ambice, zamýšlející vytvořit miniaturní verze univerza, obsahující exempláře všech kategorií věcí a pomáhající učinit viditelnou celistvost univerza, jež je jinak skryta pohledu lidských očí (viz Lidchi 1997: 158). Populární představa muzea má podobu neoklasicistního chrámu fungujícího jako truhla naplněná národním pokladem či upomínka minulosti, kterou navštěvují rodiny za deštivých odpolední, - tato představa byla ustavena na konci 19. století ve většině Evropy a v Severní Americe. Jakkoli se původ této instituce zdá být obskurní, její vývoj je velmi dobře popsán. Od jejího založení před sto lety přilákala miliony zvědavců po celém

9 „Je sice pravda, že novodobá archeologie, historie a paleontologie představují dějinně dosud nejpropracovanější a nejdokonalejší opírání př́iběhu o listinné a hmotné doklady, ale ani u nich nelze přehlédnout imaginativní složku stejně jako potlačování ,nehodících se“ hmotných památek“ (Komárek 2008: 7).

10 Politiky ve smyslu, jak o politice vystavování mluví Lidchi, tedy souhry moci/vědění.

11, „V tomto smyslu je pro naši diagnózu cenný. Nikoli proto, že by nám umožnil vytvořit tabulku našich distinktivních rysů a předem načrtnout tvar, jaký budeme v budoucnosti mít. Ale zbaví nás našich spojitostí; rozpustí tuto dočasnou identitu, v níž se tak rádi pozorujeme, abychom odvrátili historické zlomy [...], a tam, kde antropologické myšlení zkoumalo bytí člověka či jeho subjektivitu, nechá zazářit jiné a vnějšek. Takto chápaná diagnostika nestanovuje prohlášení naší identity pomocí soustavy distinkcí. Stanovuje, že jsme diferencí, že náš rozum je diferencí diskurzů, naše historie diferencí časů, naše já je diferencí masek a že diference zdaleka není zapomenutý a znovuobjevený počátek, nýbrž právě toto rozptýlení, jímž jsme a které způsobujeme“ (Foucault 2003:56). 
světě. ${ }^{12}$ Nejnovější definice se točí kolem sbírání, výzkumu a vystavování exemplářò. ${ }^{13}$ Činnost specialistů je možné také popsat jako rituální aktivitu pečující o oltář po předcích (viz Cannizzo 1996: 382). Politika analýzy je otázkou diskurzu a moci prozkoumávat historickou přirozenost muzeí a sbírek. Existuje totiž spojení mezi vzestupem etnografických muzeí a expanzí západních států.

Muzea tedy existují, aby uspořádala, nabyla, ochránila, konzervovala a vystavovala objekty, artefakty, umělecká díla. Ovšem tato definice není definicí esenciální, nýbrž historickou. Pokud zkoumáme klasickou etymologii slova „museum“ (musaeum), nalezneme dva významy. Na jedné straně tento termín označuje mytologické místo obývané devíti bohyněmi poezie, hudby a svobodných umění; tedy místo, kde přebývají Múzy. Na druhé straně termín „muzeum“ také odkazuje ke knihovně $\mathrm{v}$ Alexandrii, $\mathrm{k}$ veřejnému místu zasvěcenému studiu a výzkumu - s potenciálem $\mathrm{k}$ dalšímu rozvoji. Muzea mohla uvést $\mathrm{v}$ soulad kuriozity a studium, privátní a veřejnou doménu, rozmarnou nevyzpytatelnost i uspořádávání a klasifikaci světa. Během 16. a 17. století byla udělena sbírkám, archivům a podobným místům paměti různorodá terminologie odvislá od sociálního a kulturního umístění sběratelů. Během této doby, před zákony ustavujícími muzea v moderním slova smyslu, existovala místa jako Wunderkämmer, Kunstkämmer a různá další „divadla př́rody“, či „kabinety kuriozit“ (viz Lidchi 1997).

Současně s historií a muzeologií ale vzniká další věda, věda o paměti jako alchymii podstatného. Tou je další moderní věda o čase - archeologie. I tato stojí u vzniku a vytváření ideje kontinuity a linie mezi minulostí, přítomností a budoucností. Vzniká tak specifický druh vědění o časoprostorech a věcech. Termín ,,arché“ ( puvod, počátek) jako hledání počátku se ujal pro označení „,vykopávkových praci“", hledajících a interpretujících hmotné stopy minulých kultur, a později byl přenesen na všechny činnosti zabývající se odkrýváním zapomenutých a časem zanesených věcí, viz například Foucaultovu „,archeologii vědění“. Pro náš text můžeme přemýšlet o jakési archeologii vědění o genech, vědění odhalujícím naše dávné kořeny a původ skrze ideu dědičnosti. $O$ vědění reprezentovaném v Mendelově muzeu.

\section{Mendelovo muzeum}

Je to jenom malý trik, ale dlouhé vyprávění, které by zabralo př́liš mnoho času. ${ }^{14}$

(J. G. Mendel)

„Přibližně před 150ti lety se na zahradě Opatství svatého Tomáše na Starém Brně začal řeholník jménem Gregor Johann Mendel (1822-1884) zabývat experimenty s křížením

12 „Vidíme-li třeba expozice Britského muzea, je z nich dobře patrné, že ,seriózní archeologie a muzeologie se plynule vyvinula ze slídění po pokladech a jejich vykopávání - mnohé z těch, které jsou vystaveny v jeho vitrínách, by rozhodně dělaly čest i kapitánu Flintovi““ (Komárek 2008: 6).

13 Zkrátka, jak objekty, texty či fotografie spoluvytvářejí reprezentace jednotlivých lidí a komunit $\mathrm{v}$ přesně definovaném historickém momentu.

14 Viz http://www.mendel-museum.com/ces/1online 


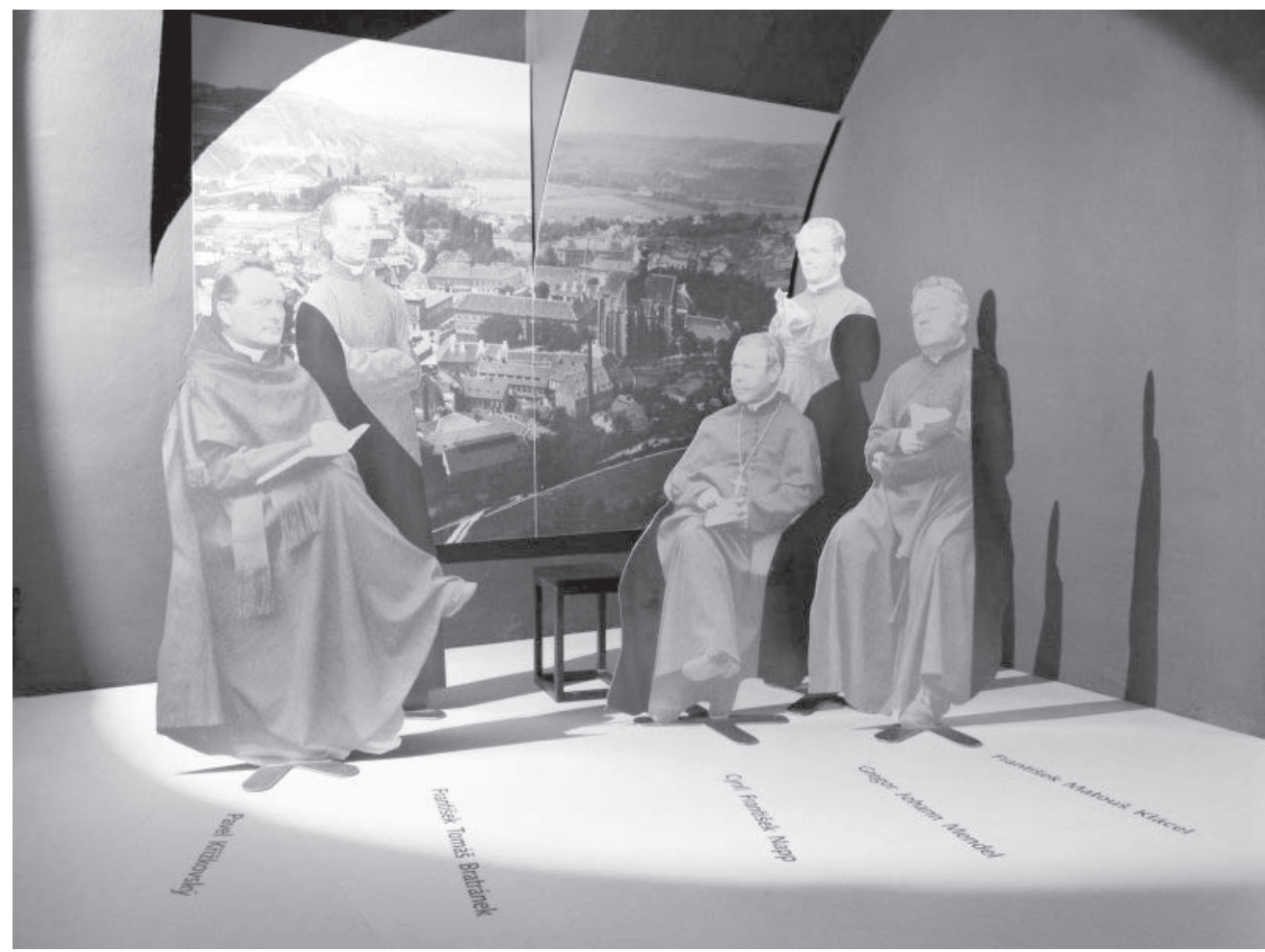

hrachu. Na základě jeho objevů pak vznikla nová věda - genetika."“15 Tolik krátké konstatování na úvod, pocházející z doprovodných textů výstavy Mendelova muzea na Mendelově náměstí, které funguje pod hlavičkou Masarykovy univerzity v Brně. Johan Gregor Mendel je považován za jednoho z otců zakladatelů genetiky, člověka, který geniálním způsobem sto let pred popisem DNA předjímal vznik této vědy o dědičnosti.

Když Mendel prováděl své pokusy s hrachem Pisum sativum, zjistil, že znaky různých odrůd hrachu (např́íklad žlutá barva nebo svraštělý lusk), se v určitém poměru dědí u potomstva. Byla to první představa o jednotkách, které dnes nazýváme „geny“, objev, který znamenal zásadní posun v biologii a položil základy moderního biomedicínckého výzkumu.

(Propagační materiály Mendelova muzea)

Kromě muzea vzniká Mendelovo centrum, jehož hlavním záměrem je připomenutí, vzpomínání na Mendela, který žil ve zdejším augustiniánském klášteře. Tato instituce má znovuobjevit opatství a být centrem vědeckého výzkumu, komunikace a vzdělávání. Muzeum

15 Viz http://www.mendel-museum.com/ces/1online 
či centrum nabízí i genetickou poradnu, v rámci které lékařka odpovídá na dotazy těch, kteří si nejsou jisti svojí či rodinnou zátěží. ${ }^{16}$

Instituce Mendelova muzea v sobě slučuje různé funkce, záměry a významy. Zdařile v sobě spojuje, tak jako většina současných muzeí, vědu a umění. Kombinuje historické předměty s interaktivní počítačovou technologií a výtvarnými díly současných evropských umělců. Expozice reprezentuje převratné vědecké myšlenky prvního genetika srozumitelným způsobem a nabízí pozoruhodný vizuální zážitek. Mendelovo muzeum také zpř́itomňuje př́irodu, kategorie přirozeného, ukazuje, jak také lze uvažovat o člověku a jeho historii právě jako o tvoru umístěném v univerzu času a prostoru. DNA ale také funguje jako místo interpretace, stejně tak jako kontinuita/diskontinuita v čase a vývoji vědeckého popisu člověka. Anton Markoš, teoretický biolog, uplatňuje na analýzu DNA hermeneutický př́istup (viz Markoš 2000), tedy takové čtení kódu, takovou perspektivu, že ani geny nenesou esenciální významy, že tak stejně jako neurony nebo smyslové vzruchy nenesou esenciálně ideu času, toho, co je minulost, př́ítomnost a budoucnost. Proto ani DNA není jednoznačnou předpovědí, jediným minulým či budoucím osudem našich životů.

\section{Vzpomínky na budoucnost?}

\section{DNA, genom - proč?}

Roku 1953 sestavili James Watson a Francis Crick model deoxyribonukleové kyseliny, za což jim byla roku 1962 udělena Nobelova cena za fyziologii a lékařství. Z hlediska věd o člověku se tento „objev“"17 stal jednou z nejvýznamnějších událostí dvacátého století. Následovalo období, ve kterém představy o genech jakožto stavebních jednotkách nejen DNA, ale všeho živého, ovlivnily a ovlivňují pojetí člověka, kontinuity či dědičnosti. Tato genomizace společnosti je ale také předmětem zájmu věd sociálních, protože je součástí širšího proudu jevů souvisejících se specifickou moderní perspektivou populace vnímanou skrze tělesnost, skrze koncept života. Důraz na tělo a na bios, tedy na kategorii živého, stojí v základech moderního procesu vytváření a správy populace prostřednictvím biomoci/biopolitiky - konceptu, který popsal ve svých textech Michel Foucault. ${ }^{18}$ Jeho současné projevy shrnují Paul Rabinow a Nicholas Rose ve svém textu Biopower Today, kde mluví o hlavních

16 V květnu roku 2002 Centrum zahájilo svoji činnost konferencí „EMBO Workshop, Genetics after the Genome“, Akademie věd ČR a společnost VFG (Vereinigung zur Förderung der Genomforshung) následně uspořádaly sérii přednášek pod názvem „The Road to and from DNA: A Celebration of 50 Years of the Double Helix“, aby si tak prripomenuly výročí objevení struktury DNA $\mathrm{v}$ roce 1953 Watsonem a Crickem (http://www.mendelmuseum.muni.cz).

17 Důvod, proč dávám slovo „objev“ do uvozovek, je ten, že epistemologie převládajícího paradigmatu př́rodních věd vychází z předpokladu, že objevuje již existující ontologické struktury, jevy, zákonitosti. Epistemologická perspektiva, ze které vycházím v tomto textu, tzn. interpretativní, konstruktivistická věda, je však jiná. Základem mojí argumentace je to, že neexistují ontologická jsoucna, která by měla smysl sama o sobě a jejichž význam by nesouvisel s interpretací, která je jim $\mathrm{v}$ různých vědeckých, politických či popularizačních interakcích přiřčena. Napríklad The Birth of Biopolitics, Déjiny sexuality - Vưle k vědèní ad. 
projevech biomoci: ideji rasy, reprodukční medicíně a genomice. Pozornost věnovaná reprezentacím tělesnosti, konkrétně DNA a idejím o diverzitě populací, je v této souvislosti důležitým předpokladem sociálněvědní konceptualizace nových hranic subjektivity, identity či přináležitosti $\mathrm{k}$ nacionální komunitě.

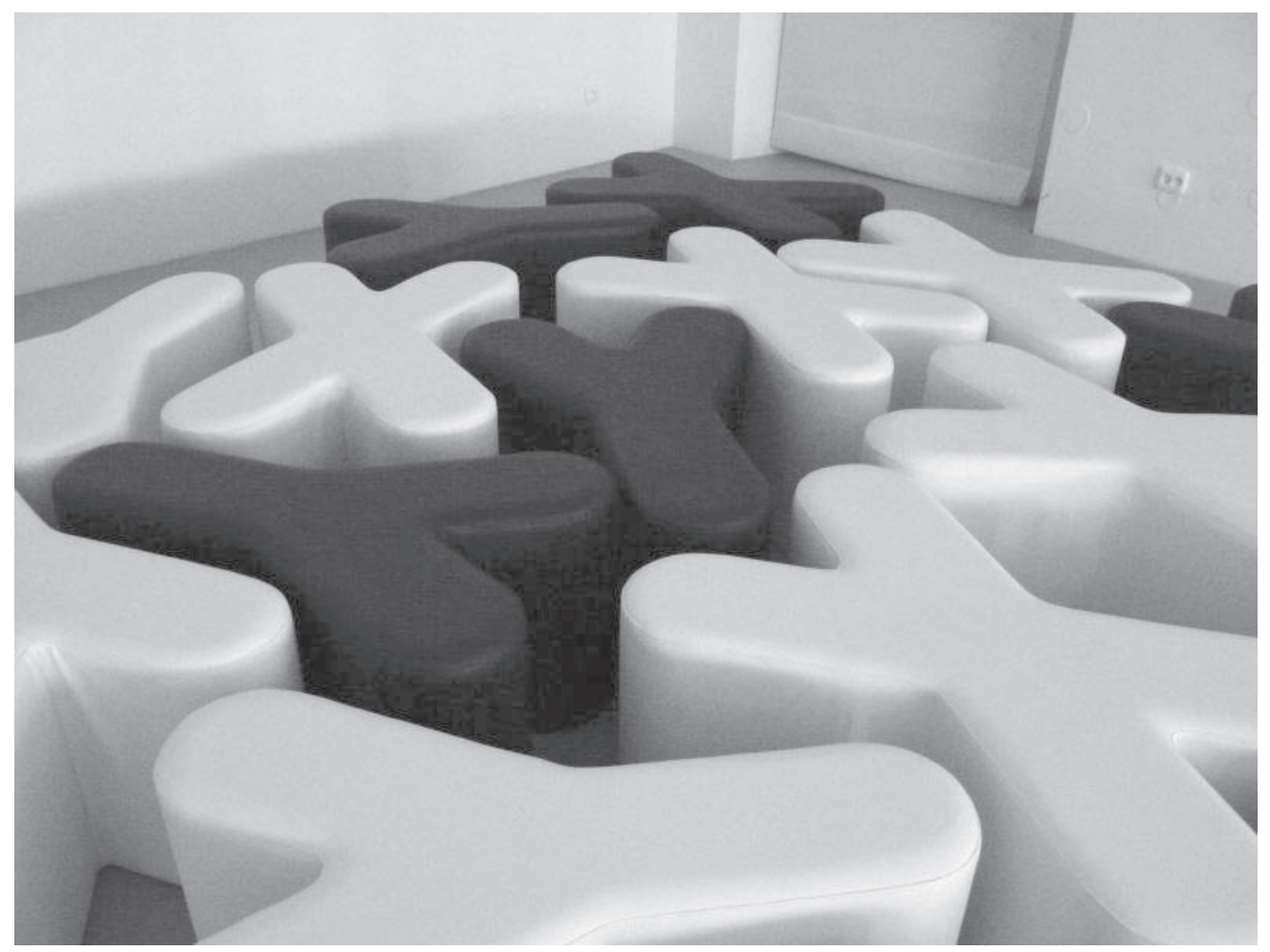

Praktické vědění si uvyklo chápat a vnímat tělo jako součást přirozenosti, přírody, něčeho, co je dědičné, opravdové, autentické, a také něčeho, co má vývoj v čase. Pokud se $\mathrm{k}$ tomu $\mathrm{v}$ případě reprezentací analýzy DNA přidá autorita expertního vědění, přispívají tyto výpovědi $\mathrm{k}$ ospravedlnění esencializace tělesných rozdílů mezi lidmi jakožto rozdílů „přirozených“, „pravdivých“. Sociální vědy nám ale mohou ukázat, že hranice mezi tím, co je Jiné a co je Stejné, nebo mezi tím, co je přiřazeno ke sfére přirody a co ke sfére kultury, je značně variabilní a sociálně vytvářená (viz Wade 2002, Haraway 2002). Tudíž že z perspektivy sociálních věd je důležité zkoumat podmínky konstrukce pravdivosti, autenticity či přirozenosti těchto hranic. ${ }^{19}$

19 Viz text E. Šlesingerové Imaginace národních genů a vtělená sociální teorie (disertační práce, FSS MU 2008). 


\section{Utopie... umístění snu o jistotě identit}

Mendelovo muzeum nám připomíná prvopočátky genetiky, staví do konzistentní linie ideu dědičnosti, reprezentovanou Mendelovým výzkumem hrachu, aby se z muzea, této archivace minulosti, stalo místo budoucího vědeckého rozvoje. Již jednou jsme zmínili Foucaultovu definici utopie jako umístění bez skutečného místa. Utopie, to je podle něj dokonalá společnost sama, jsou $\mathrm{v}$ každém př́ípadě místy $\mathrm{v}$ zásadě neskutečnými (viz Foucault 2003). Může být muzeum reprezentací účinně zavedené utopie? Může Mendelovo muzeum skrze reprezentaci touhy po kontinuitě, po ustavení linie dědičnosti skrze vzpomínání na jistý typ minulého výzkumu utopicky spojovat s touto minulostí výzkum budoucí, sen o umístění člověka, jeho DNA, v časovém kontinuu?

Mendelovo muzeum ale reprezentuje také veliký moderní príběh o jistotě identity, který, zdá se, lze v tomto př́padě umístit do kulis příběhu o nalezení kořenů díky DNA. Jde o sen o nalezení kolektivní paměti a identity?

Dne 26. června 2000 dva na sobě nezávislé vědecké týmy oznámily, že bylo dokončeno mapování lidského genomu v rámci tzv. Human Genome Project (Projektu mapování lidského genomu). Od osmdesátých let, kdy snaha rozluštit lidskou DNA započala, vznikly další projekty, zvláště potom HGDP - Human Genome Diversity Project (Projekt mapování genomické diverzity) nebo populárně vědecký projekt o světové migraci pod záštitou společnosti National Geographic. Analýza fenoménu spojování části DNA a etnických či národních př́slušností poukazuje na nutnost sociologické a sociálně antropologické re-konceptualizace kategorií rozdílnosti a stejnosti, diverzity lidských populací, osobní i sociální identity, príbuzenství, nacionální př́slušnosti apod.

Důvodem, proč zde zmiňuji DNA ve spojitosti napřed s J. G. Mendelem, pak s DNA a projektem HGDP, proč je tedy tak zajímavé vyjít $\mathrm{z}$ príkladu a $\mathrm{z}$ reprezentace genealogie genetiky, kterou nabízí Mendelovo muzeum, je to, že je jedním z mnoha. ${ }^{20}$ Po celém světě vznikají projekty, které ve snaze najít Motherland, ${ }^{21}$ podnikají genetickou pout', nabízejí cestu do minulosti, ke kořenům, a skrze tuto podniknutou pout' potom cestu $\mathrm{k}$ jistotě o vlastní identitě. Tato pout' tedy není pouze cestou geografickou přes moře, hory, státní hranice; je cestou mytologickou přes stovky generací, cestou k předkům. Je tedy př́íladem utopie, tzn. umístění snu o jistotě o vlastní minulosti, o vlastním původu do neskutečného, protože již neexistujícího světa.

\section{Na konec...}

Část textu nazvaná „Vzpomínky na budoucnost“ poukázala na to, jakou roli hraje idea dědičnosti, kořenů $\mathrm{v}$ reprezentaci linie spojující minulost, př́tomnost a budoucnost. Opravdovost této reprezentace získává na síle odkazováním na a spojováním s něčím takovým, jako jsou geny, genetika. Způsob, jakým muzea re-prezentují moderní a modernistickou ideu vzpomínání na vývoj člověka, legitimizovanou časem, na jeho dědičnost a zároveň

20 Zajisté unikátní svým vzpomínáním na otce zakladatele, který působil na místě autentické vzpomínky.

21 Viz http://www.sciencemuseum.org.uk/antenna/motherland 
jeho budoucnost, byl ukázán na př́kladu poutě k jistotě vlastních kořenů. Muzeum genetiky, archiv mimetického zobrazení skutečnosti lidství $\mathrm{v}$ jeho esenci par excellence - tedy skrze DNA genom - nás zároveň odkazuje $\mathrm{k}$ mytologické podstatě chápání př́rodní historie a místa člověka v ní. Ke hledání kontinuity, jistoty prostřednictvím splétání a lpění na časové linii. Nabízí se otázka: Nikdy jsme nepřestali být moderní?

První část textu ukázala na souhru individuální a sociální paměti, na dichotomii mezi pamětí a historií. Druhá část, „Místa paměti - muzea“ a „Muzeum J. G. Mendela“, poukázala na konkrétním př́íladu na západní modernistickou linii kontinuity minulosti, př́tomnosti a budoucnosti. Poslední kapitola, „Vzpomínky na budoucnost“, ukázala, jak je budoucnost v tomto pojetí času (moderní linie) integrální součastí minulosti, vzpomínání a zapomínání. Naznačila tedy, jakým způsobem dochází $\mathrm{k}$ vyprávění smysluplného př́iběhu o člověku. V tomto textu jsme ukázali, že pamět' je stejně tak individuální, jako sociální, je součástí osobní i sociální identity, je její podmínkou nutnou. Funes el Memorioso se na konci našeho textu jakoby vytrácí v mysteriózní postavě, která neumí strukturovat svět kolem sebe. Na rozdíl od obyvatel Maconda, kteří - než by ztratili jistotu v popisu světa - vymysleli imaginární, ale útěchy plnou skutečnost.

Nápis, který pověsil na šíji krávě, byl př́ikladnou ukázkou toho, jak obyvatelé Maconda hodlají bojovat proti ztrátě paměti. Tohle je kráva, každé ráno je potřeba ji podojit, aby dala mléko, a mléko je potřeba svařit, smichat s kávou a udělat bílou kávu. A tak tu žili uprostřed kluzké skutečnosti, kterou na okamžik zachytili slovy, jež jim však musela neodvolatelně uniknout, jakmile by zapomněli, co znamená které písmeno. Na cestě od bažiny postavil na okraj městečka nápis Macondo a na hlavní ulici ještě větší, jenž ohlašoval Bůh je. V každém domě visely nápisy, které jim připomínaly názvy věcí a pocitů. Tento způsob však vyžadoval tolik bdělosti a mravní síly, že mnozí podlehli kouzlu domnělé skutečnosti, kterou si sami vymýšleli a která jim připadala snad méně účelná, ale o to útěšnější.

(Márquez 2003)

V čase nespavé nemoci, při které se ztrácí pamět', se José Arcadio Buendía i obyvatelé Maconda snažili nalézt postup, jak uniknout této chorobě, a jakýmsi chlácholivým způsobem ho našli v neustálém pojmenovávání věcí, objektů, pocitů a ve vyrábění vzpomínek či věštění minulosti. Stejně tak i aktéři pozdní modernity každodenně žijí v budování více či méně domnělých skutečností a útěšných minulostí, které si sami konstruují a kterými jsou zároveň zpětně ovlivňováni. Budují a boří minulosti v toku př́tomných významů a jejich neustálé přetváření je součástí jejich minulých, současných i budoucích společně sdílených sociálních světů, ve kterých vyjednávají a projasňují či zviditelňují osobní i sociální identity. A stejně jako obyvatelé Maconda, tak i Funes el Memorioso řeší čas - neumí ovšem rozlišit nepodstatné od důležitého, nerozlišuje priority, neumí zevšeobecňovat, nedokáže si vytvořit obecné představy. Borges dochází k závěru, že podstatou našeho lidství snad není pouze zapamatování, nýbrž i naše zapomínání. Myslet podle Borgese znamená vybírat, zvýznamňovat. Pamět' je tedy podle něj součástí naší identity. Tento text narazil skrze pár př́ikladů na sen o neselhávající paměti, moderní touhu po dokonalosti pomocí institucionalizovaného zachycení času a zároveň na snahu udržet minulost, kořeny, př́tomnost a budoucnost jako součásti jednoho smysluplného a smysl dávajícího vyprávění. 
Vzpomeňme naposled na konci našeho textu na Funese a nechme jej už konečně žít v klidu jeho literární život. Díky inspiraci jeho př́ípadem lze tedy říci, že kromě důrazu na zapomínání jako integrální část paměti můžeme konstatovat spolu s Friedrichem Nietzschem, jenž se vysmívá snahám proměnit pamět' ve vědu, tedy historii, že je důležité, snažit se porozumět každému vědění o čase i jednání na něj orientovanému a tyto dále hermeneuticky interpretovat. Nietzsche se totiž vysmívá iluzi o možnosti úplného vysvětlení, dosažení objektivity. Př́ítomnost je symetrická vůči minulosti a budoucnosti a rozvržení budoucnosti je vždy projekcí toho, jak jsme integrovali minulost do přítomné chvíle:

Výrok minulosti je vždy výrok věštecký: jen jako budovatelé budoucnosti, jako věštci př́tomnosti mu porozumíme. Mimořádně hluboký a rozsáhlý účinek Delf se nyní vysvětluje zejména tím, že delfští kněží byli důkladnými znalci minulého.

(Nietzsche in Markoš 2003) ${ }^{22}$

\section{Literatura}

BORGES, Jorge. Funes el Memorioso. Muž se zázračnou pamětí. In Zrcadlo a maska. 1. vyd. Praha : Odeon, 1989. $448 \mathrm{~s}$.

CANNIZZO, Jeanne. Museums. In BARNARD, A., SPENCER,J. (eds.). Encyclopedia of Social and Cultural Anthropology. London, New York : Routledge, 1996, s. 382 - 384. ISBN 041520318X.

ERIKSEN, Thomas Hylland. Sociálni a kulturni antropologie: př́buzenství, národnostní př́slušnost, rituál. 1. vyd. Praha : Portál, 2008. 407 s. ISBN 978-80-7367-465-6.

FOER, Joshua. Pamatujte si to. National Geographic, 2007, s. 58 - 84. ISSN 0027-9358.

FOUCAULT, Michel. Myšlení vnějšku. 2. vyd. Praha : Hermann \& synové, 2003. 304 s.

HARAWAY, Donna. Manifest kyborgů : věda, technologie a socialistický feminismus ke konci dvacátého století. Sociální studia 7, 2002, s. 51 - 59. ISSN 1214-813X.

KOMÁREK, Stanislav. Archeologie. In Labyrint. 2008.

LIDCHI, Henrietta. The Politics and Poetics of exhibiting other cultures. In STUART, H. Representations. 1. vyd. London : SAGE Publications, 1997, s. 151 - 223. ISBN 978-0761954323.

LÉVI-STRAUSS, Claude. Myšlení př́rodnich národi̊. Praha : Dauphin, 1996. $366 \mathrm{~s}$.

MARKOŠ, Anton. Tajemstvi hladiny. Hermeneutika živého. 1.vyd. Praha : Dokořán, 2000. 366 s. ISBN 808597732X.

MÁRQUEZ, García Gabriel. Sto roků samoty. 3. vyd. Praha : Odeon, 2003. 320 s. ISBN 80-207-1139-2.

METYKOVÁ, Monika. Imaginárne domoviny : vymiestenie v tvorbe Salmana Rushdieho. Sociálni studia, 2004, č. 2, s. 71 - 78. ISSN 1214-813X.

MISZTALl, Barbara A. Theories of social remembering. Maidenhead : Open University Press, 2003. 168 s. ISBN 978-0335208319.

NIETZSCHE, Friedrich. Nečasové úvahy. O užitku a škodlivosti historie pro život. 1. vyd. Praha : OIKOYMENH. 2005. 296 s. 80-7298-134-X.

NORA, Pierre. Mezi pamětí a historií. Problematika míst. In Politika paměti : antologie francouzských společenských věd. Praha : CEFRES, 1998.

22 Za nápad začlenění úryvku vděčím knize Antona Markoše Tajemství hladiny. Hermeneutika živého. 
Eva Šlesingerová: Funes el Memorioso navštěvuje muzeum aneb vzpomínky na budoucnost

RABINOW, Paul ; ROSE, Nikolas. Thoughts On the Koncept of Biopower Today. [online]. 2003, [cit. 2009-11-15]. Dostupná na www: <http://caosmosis.acracia.net/wp-content/uploads/2009/04/rabinow-y-rose-biopowertoday-1.pdf $>$.

TODOROV, Tzvetan. Zneuživání paměti. In Politika paměti : antologie francouzských společenských véd. Praha : CEFRES, 1998.

WADE, Peter. Race, Nature and Culture : An Anthropological Approach. London : Pluto Press, 2002. 160 s. ISBN 0745314546.

WHITE, Heyden. Historicismus, historie a figurativní obraznost. Reflexe(filosofický časopis), 1998, č. 16, s. 2. ISSN 0862-6901.

\section{Propagační materiály z výstavy Mendelova muzea}

(Navštíveno 10. února 2009.)

www.mendelmuzeum.muni.cz

http://www.museumofman.org

http://www.musmn.de

http://www.museum.manchester.ac.uk

http://www.sciencemuseum.org.uk/antenna/motherland

\section{Autorka}

působí na Katedře sociologie, oboru Sociální antropologie Fakulty sociálních studií Masarykovy univerzity, kde vyučuje předměty Současná sociální a kulturní teorie, Sociální antropologie a historie tělesnosti, Rasismus a idea „rasy“ a další. Zabývá se tématy konstrukce sociálních a kulturních identit, tělesnosti a jejich reprezentacemi v populární kultuře.

Kontakt: eslesi@fsss.muni.cz 